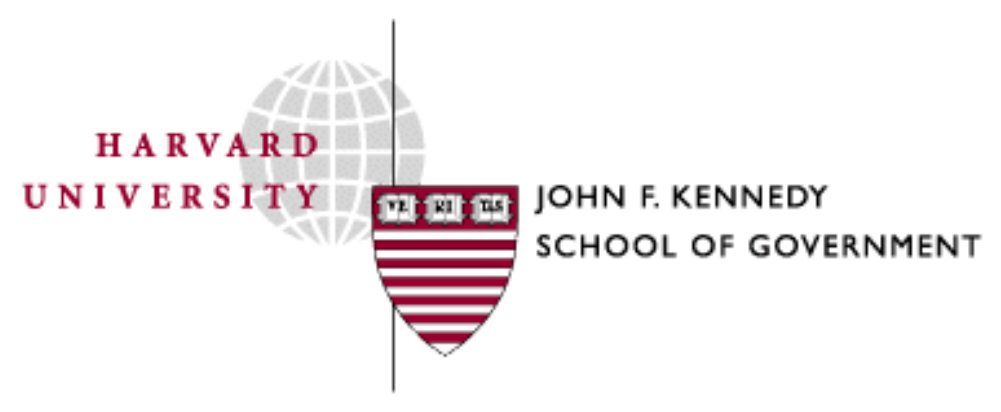

Faculty Research Working Papers Series

\title{
Decentralization in Pakistan: Context, Content and Causes
}

\section{Ali Cheema, Asim Ijaz Khwaja, and Adnan Qadir}

April 2005

RWP05-034 belongs to the author(s). Papers may be downloaded for personal use only. 


\title{
Decentralization in Pakistan: Context, Content and Causes*
}

January 2004

\author{
Ali Cheema \\ Assistant Professor \\ Department of Economics, \\ Lahore University of Management Sciences \\ Asim Ijaz Khwaja \\ Assistant Professor of Public Policy \\ John F. Kennedy School of Government \\ Harvard University, MA \\ Adnan Qadir \\ Senior Research Associate \\ Pakistan Administrative Staff College
}

INTRODUCTION

I. HISTORY OF DECENTRALIZATION IN PAKISTAN …............................................................................. 1

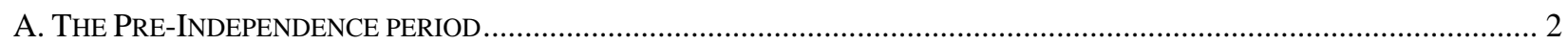

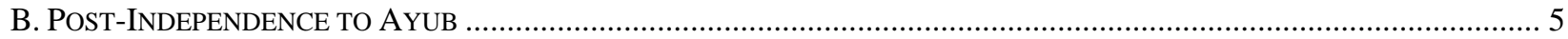

C. The Ayub Period: DeCentralization And the Politics of Legitimacy ……................................................. 6

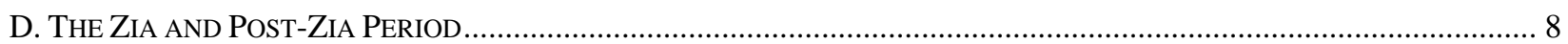

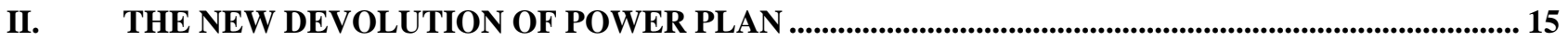

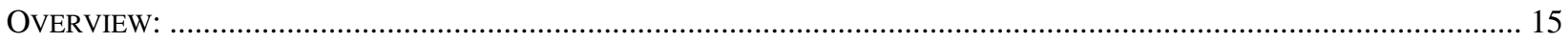

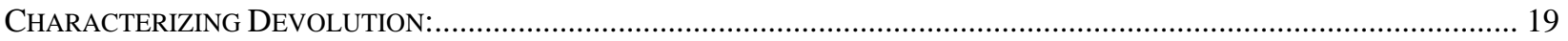

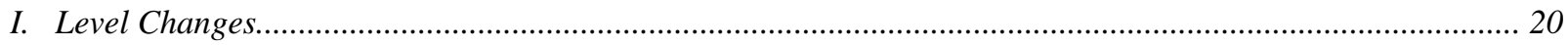

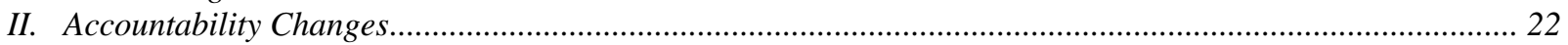

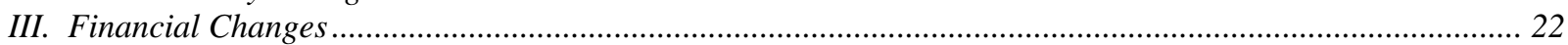

III. THE POLITICAL ECONOMY OF DECENTRALIZATION......................................................................... 24

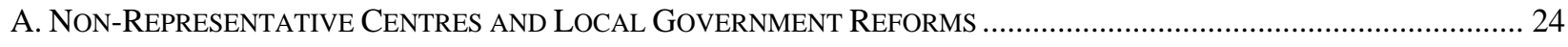

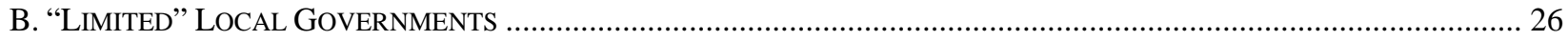

C. Distortions AND CONFLICTS IN POLITICS- LOCAL GOVERNMENTS VERSUS THE PROVINCE? ............................... 26

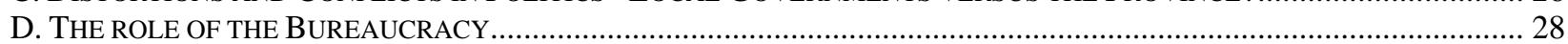

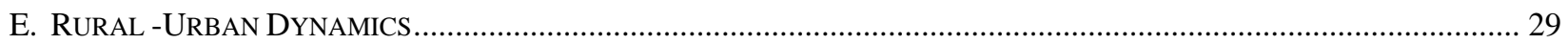

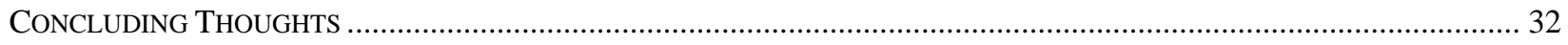

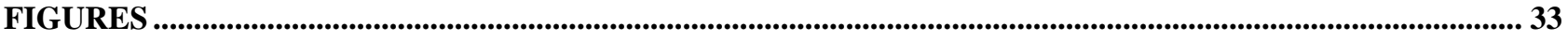

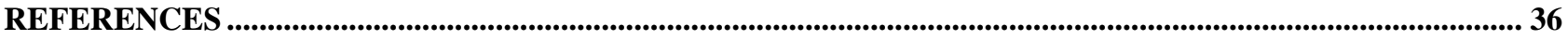

APPENDIX A: CHRONOLOGY OF LOCAL GOVERNMENTS IN PRE- AND POST INDEPENDENCE

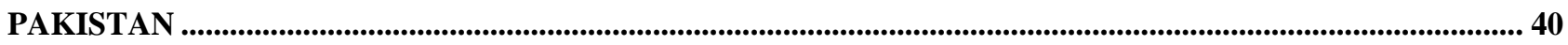

APPENDIX B: THE ELECTORAL MECHANICS OF THE LOCAL GOVERNMENT ................................. 41

\footnotetext{
*Contact: cheema@lums.edu.pk; akhwaja@ksg.harvard.edu; adnanqadir@hotmail.com; The authors would like to acknowledge invaluable research assistance provided by Usman Talat, Mariam Mufti and Ali Fareed Khwaja. We would like to thank Reza Ali, Haris Gazdar, Shandana Mohmand and Anjum Nasim for their comments.
} 


\section{Introduction}

This paper provides a description of the recent decentralization reforms in Pakistan under General Musharraf. In the process, we hope to not only highlight major aspects of this reform, but also to analyze the evolution of this reform in historical context in order to better understand the potential causes behind the current decentralization. Analyzing the evolution of local government reforms in Pakistan is interesting because each of the reform experiments has been instituted at the behest of a non-representative centre using a ‘top down’ approach. The Pakistani experience shows that each of the reform experiments is a complementary change to a wider constitutional reengineering strategy devised to further centralization of political power in the hands of the non-representative centre. We argue here that the design of the local government reforms in these contexts becomes endogenous to the centralization objectives of the non-representative centre. It is hoped that analyzing the Pakistani experience will help shed light on the positive political economy question of why non-representative regimes have been willing proponents of decentralization to the local level.

Section I provides a historical overview starting with the pre-independence period up to the revival of local governments under General Musharraf. Section II then provides a description of salient features of the current decentralization reform. Finally, section III interprets the current reform in light of the historical context outlined in section I.

\section{History of Decentralization in Pakistan}

While providing a detailed history of local governments is beyond the scope of this paper, it is instructive to mention aspects of this history that shed light in understanding the current decentralization reforms (see Appendix A for a chronology of major local government events). In particular, after briefly examining the pre and post independence period, we spend some time looking at the two most significant decentralization reforms, both interestingly also at the behest of military regimes under Generals Zia-ul-Haq and Ayub Khan respectively. The sections below are organized in a coarse chronological manner since the objective is not to provide an in-depth historical account but rather to focus on particular aspects of local governance in what is now Pakistan. 


\section{A. The Pre-Independence period}

Pre-existing Local Governments: Before the advent of the British rule in India, there was no advanced tradition of local self-government in the modern sense. However, a rudimentary local government system did exist in the rural areas. This was the system of village panchayats (literally council of five) which performed administrative, judicial and sometimes developmental functions (Majumdar 1960, Basham 1954). However, in terms of representation, the Panchayat was only rarely representative of the village as a whole, often representing the founding-families, upper castes and large farmers (Siddiqui 1992, Drummond 1937, Sand 1976). It is also worth emphasizing that Panchayats were not the only form of village government in pre-British India. The system of village headmen is one example of other forms of rural government although "under the reign of the Moguls and the time of the British government the headman was more a representative of the central government rather than of village self-government.” (Siddiqui 1992, Sand 1976)

Local Governments under the British: In the areas that presently comprise Pakistan, local governments were introduced by the British not by building on the village panchayats, but instead from scratch, following the annexation of Sindh in 1843 and of Punjab in 1849 (Nath 1929, Tinker 1968, Venkatarangaiya and Pattabhiram 1969). After the War of Independence (or Indian Mutiny) of 1857, with the governance of India transferred from the hands of the East India Company to the Crown, attempts were made to co-opt the native elite by establishing representative local governments. These local governments were formed in a "top-down" manner in urban and rural areas, with extremely circumscribed functions and members who were not locally elected but nominated by the British bureaucracy. However, despite legislation for setting up district committees in almost every province, "The Committees were nothing more than a convenience to the District Magistrate to supply him with information or to carry out miscellaneous duties ... Village life was hardly touched by the new District Committees. They were formed by the District Magistrate from among his 'mulaqatis's' and other respectable citizens. The official influence was almost over-powering” (Tinker 1968). Instead, substantive local control was maintained by the centre through the office of the Deputy Commissioner $(\mathrm{DC})^{2}$, an integral part of the central

\footnotetext{
${ }^{1}$ Visitors of the District Magistrate.

${ }^{2}$ Formerly called Collector.
} 
bureaucracy, who as the chief executive of the district ${ }^{3}$ emerged as the most important agent at the local level (Ahmed 1964).

Democratic Processes at the Provincial Level: The outbreak of World War I and agitations by nationalist parties, demanding greater representation in provincial and central governments, shifted focus away from local governments and prompted the British government to make political concessions to Indian political parties by granting more autonomy at the provincial level. In fact, in response to these changes local government became a transferred subject to be administered by a provincial Indian minister in 1919. These changes are important in understanding the evolution of local governments since they sharpened the contrast between these nascent representative governments at the centre/province and the existing local governments, as the latter became less relevant as means of representation; the public debate having shifted to the more regional and central arena of the nationalist movement. This shift in political emphasis was a major factor behind the dormancy of local governments in the areas that were to constitute Pakistan (Rizvi 1976). The first significant constitutional accommodation to regional representation came in the form of the Government of India Act 1919 that introduced a system of dyarchy under which Indian ministers responsible to the provincial legislative assemblies were made in charge of some minor departments. This Act, while granting limited space to Indian politicians, essentially retained the control of the central imperial bureaucracy; in fact bureaucratic power at the provincial level was further entrenched through key changes in the government rules of business. ${ }^{5}$ The space available to Indian elected ministers was further curtailed by the limited assignment of expenditure functions and fiscal resources (Kumar 1982).

The growing strength of the Indian Nationalist movement prompted the introduction of the most significant step towards provincial autonomy, which came with the Government of India Act, 1935. The India Act of 1935 established a federal form of government and introduced "fully responsible” government in the provinces. It expanded the set of expenditure functions assigned to elected Indian provincial governments and was buttressed by the 1937 Niemeyer Award, which was the first attempt at fiscal federalism in India (Kumar 1982). However, despite these significant measures the

\footnotetext{
${ }^{3}$ The district was the principle unit of government in Colonial India.

${ }^{4}$ The DC's main functions included executive magistracy (including law and order), revenue collection, general administration at the district level and coordination of service delivery.

${ }^{5}$ For example: "A provision was made in the rules of business which was to have far reaching consequences later on in Pakistan. It enabled bureaucrats to defy their elected ministers. The rule was that where there was a difference of opinion between a secretary and his minister, the secretary could go behind the back of the minister and obtain a ruling direct from the governor.” (Alavi 2001, pg. 18).
} 
control of the Imperial Centre over the provinces was retained through considerable discretionary reserve powers that were granted to the non-elected provincial governors.

Patronage and Rural Biases under the British: Another important feature of the British system of local government was the creation of a rural-urban divide. Urban local councils were established by the British to provide essential municipal services in urban areas where they resided. It appears that rural councils were explicitly used to co-opt the local elite by giving them limited representation and as a result their capacity to provide essential municipal services became even more circumscribed than the capacity found in urban areas (Siddiqui 1992).

An interesting aspect of British institution building was the centre's management of urban and rural political and economic competition. The British centre used the district bureaucracy and central and provincial policies to co-opt and entrench local elites through a selective but extensive system of patronage (van den Dungen 1972). This was particularly true of the Punjab where the colonial bureaucracy had ample opportunities for providing patronage through land settlement policy, grant of colony lands in the canal colony districts of Punjab and the use of protective legislation like the Punjab Land Alienation Act 1900 and the Punjab Pre-Emption Act, 1913 which prohibited transfer of land from agricultural to non-agricultural classes (Ali 1988, Pasha 1998, Alavi 2001). Metcalfe (1962) comments: "Status was to replace contract as a criterion of landholding; rural society was to be preserved in its traditional form by a paternal government free of theoretical principles”.

The Punjab tradition of establishing patron-client relationships between the state bureaucracy and local elite resulted in a rural-urban division, which restricted politics away from the urban middle classes. Safeguarding the loyal landowning classes from economic and political domination by the urban elites became colonial policy (Talbot 1996). The colonial political calculus reflected the need to maintain a politically acquiescent recruiting ground for the army (Pasha 1998) and the need to maintain political stability in the majority population, which resided in rural areas (Hamid 1980). The dominance of the Unionist Party (representing large landowners of all religions) in Punjab's politics during the early decades of this century was a direct manifestation of this phenomenon.

Thus what emerges from this history of local governments as created under the British is that the system was not introduced in response to popular demand or local pressure, but primarily as a result of the central government's initiative and functioned under the imperial bureaucracy's control. 
Moreover, from the beginning, there was a contradiction between the development of autonomous local self-governing institutions and the imperial interests of creating a loyal native class, and it is the latter that dominated. The rise of organized political strength and political parties during the early twentieth century was accommodated by granting more political space at the provincial level. As a result the provincial and central tiers emerged as the hub of political activity, which not only shifted political focus away from local governments, but also resulted in a lack of ownership to build local governments by political elites that were active in the Pakistan movement. However, the provincial autonomy that was granted was heavily circumscribed and extensively loaded in favor of the non-representative bureaucracy at the imperial centre.

\section{B. Post-Independence to Ayub}

Given that the independence movement was driven by political party mobilizations at the provincial and higher levels, post independence, there was understandably little emphasis on local governments which had played little role in the independence movement given their stronger ties to the British. Thus by 1947 functional local governments existed only in Punjab in the form of village panchayats and municipal councils, although with mostly non-elected members. Following independence, despite official pronouncements, ${ }^{6}$ there emerged no real commitment to the process of decentralization. Even approved decisions, such as democratizing local governments by adopting universal adult franchise and making district local bodies entirely elected, were not implemented. As before, the bureaucracy completely controlled local bodies. The local bodies were denied legitimacy by not holding elections and where elections were held, by limited 'franchise' and massive malpractices (Waseem 1994). ${ }^{7}$

The decade of the 1950s was in general marked by political instability with increasing centralization and a centre increasingly dominated by the civil and armed bureaucracy (Jalal 1995, Callard 1957, Talbot 1998). Unlike the Congress Party in India, the Muslim League in Pakistan failed to organize as a political party and to develop political bases, thus failing 'to replace the district administration as a rival source of patronage' (Waseem 1997).

\footnotetext{
${ }^{6}$ The 1948 Muslim League manifesto called for "the very widest extension of local self -government on the model of the Parishes in English”, (Rizvi 1976, pg- 33).

${ }^{7}$ Malik Feroz Khan Noon, the then Prime Minister of Pakistan, said in 1957: "It is unfortunate that so many District Boards in West Pakistan lie superseded, most of them, it would appear, for no fault of their own, but for the fact that no elections had been held after the expiry of their term”(Rizvi 1976, pg- 35).
} 


\section{The Ayub Period: Decentralization and the Politics of Legitimacy}

Following the imposition of the first Martial Law in 1958, national and provincial assemblies were disbanded and the military government immediately set about purging the political system of politicians through the promulgation of Public Offices (Disqualification) Order in March 1959. Owing to the lengthy procedure and limited scope of PODO, it was followed only a few months later by EBDO, Elective Bodies (Disqualification) Order, which was applicable to any person who had held any public office or position including membership of any elective body in the country. Thus about 6,000 politicians and officials were disqualified under EBDO (Noman 1988, Sayeed 1980, Feldman 1967).

Following the dissolution of the higher-tier elected governments, General Ayub like the British colonialists revived local governments as the only representative tier of government. The new local governments, established under the Basic Democracies Ordinance, 1959 and the Municipal Administration Ordinance 1960, comprised a hierarchical system of four linked tiers (see Figure I.1). In West Pakistan, at the lowest tier 37959 villages were divided into 3414 Union Councils, towns of less than 14,000 inhabitants were divided into 222 Town Committees and towns of more than 14,000 inhabitants into 810 Union Committees (Siddiqui 1992). This tier comprised of members elected on the basis of adult franchise who, in turn, elected a chairman from amongst themselves. The other tiers had some members elected indirectly by these directly elected members

and some official members nominated by the Government and had officials as Chairmen (Assistant Commissioner or Tehsildar in case of Tehsil Council, a government appointee in the case of Municipal Committee, Deputy Commissioner, DC, in case of District Council and Commissioner in case of Divisional Council) (Rizvi 1974).

Similar to the British period, the system was under the bureaucracy through "controlling authority" vested in the DC, Commissioner and the Government for different tiers. The controlling authority had the power to quash the proceedings; suspend resolutions passed or orders made by any local body; prohibit the doing of anything proposed to be done; and to require the local body to take some action. Although the system assigned several regulatory and development functions to the local governments, especially at the lowest tiers and at the district level, few functions could be performed due to a severely curtailed fiscal capacity (Siddiqui 1992). Thus "The Basic Democracies Scheme is not, in reality, democracy, for it does not represent control by the people over government power except in an extremely limited manner.” [Friedman, 1960 p.144] 
The most controversial aspect of the local government system was that it came to be used by Ayub to legitimize his essentially unitary Presidential Constitution (1962), which gave effective state power to the armed forces through the office of the President. The 1962 Constitution explicitly linked the office of the President to the newly created local bodies by declaring the 80,000 Basic Democrats as the Electoral College for the election of the President and national and provincial assemblies. ${ }^{8}$ The electoral function of the BD System, based on Ayub's concept of 'controlled democracy', was a carryover from the paternalistic colonial view of 'guardianship' whereby the colonial bureaucracy was supposed to guide the politicians while resisting their corrosive influences. The civil and military bureaucracy believed that Western democracy was not suitable for Pakistan because in the presence of a rural, illiterate and under developed populace, it produced weak, unstable governments. Ayub wanted to limit people’s participation to choosing a political elite or 'opinion leader' from amongst themselves. In Ayub’s own words, it was a system to "suit the genius of the people" (Khan, 1967, p 186), but for his detractors, it was a form of “representational dictatorship".

This partly bureaucratic and partly political system was used for distributing resources and patronage in order “to secure a mandate for Ayub” (Gauhar 1996, p 84) and build a constituency for the military regime (Burki 1980). The system provided many opportunities for corruption and for exercising small patronage. It was further discredited by popular perceptions of massive irregularities in the 1965 Presidential election which pitted Ayub against Jinnah's sister, Fatima Jinnah. The system was closely identified in the public mind with the military regime and popular reaction against the military regime in 1968-9 also took the form of violence against Basic Democrats. $^{9}$

There were continuities between Ayub’s management of urban and rural political and economic competition and that of the British. At the level of local governments a legislative divide was maintained between urban areas, which were governed through the Municipal Administration Ordinance (1960), and the rural areas governed by the Basic Democracies Ordinance (1959). However, Ayub, like the British, increased the share of targeted provincial and federal development

\footnotetext{
${ }^{8}$ Articles 155, 158 and 229 of the 1962 Constitution.

9 “Localized violence and rivalry sprang directly from Basic Democracies system and its Union Councils whose members and Chairmen frequently became petty tyrants, corrupt, oppressing the people they were supposed to represent” (Feldman1972, p. 255).
} 
resources in favour of the rural areas because his main source of support lay in these areas ${ }^{10}$ and these allocations reversed the significant urban bias in federal and provincial development spending that had emerged during the fifties (Cheema and Mohmand 2003, Amjad and Ahmed 1984). Rural local representatives, who formed a majority in the local government system (Rizvi 1974), were associated with development plans and projects at the local level both on account of programme $\operatorname{design}^{11}$ and because of their electoral importance in the wider state system (Rizvi 1974, Amjad and Ahmed 1984).

However, near the end of Ayub's rule the rural bias in Pakistani politics started to wane with the rise of mobilized political groups, especially in urban Punjab, during the late sixties (Burki 1972, Cheema and Mohmand 2003). An important basis for these mobilizations was provided by the rapid rate of urbanization achieved in Pakistan during the fifties and sixties. ${ }^{12}$ High rates of urbanization were caused by a massive population transfer from Muslim minority areas in India during the forties and fifties (Burki 1991, Ali 2003) and because of the high rate of rural-urban migration (Sayeed 1995). A more important basis was provided by the volatile nature of urban politics (Burki 1971) and by Zulfiqar Bhutto’s success in organizing middle class groups in urban areas (Addleton 1992). By the late-sixties, urban areas in the Punjab had become important focal points of anti-Ayub mobilizations led by lawyers, students, journalists, organized labour and other urban professionals (Wilder 1999). It was these groups, supported by the rural middle classes that provided the basis for Bhutto’s People’s Party’s political ascendancy during the late sixties (Zaidi 1999). These political changes had important consequences for the evolution of the local government system.

\section{The Zia and Post-Zia Period}

Local Government Reforms 1979-85: After a nascent period under Bhutto ${ }^{13}$, local governments were revived by General Zia ul Haq. Like Ayub, Zia ul Haq’s military regime combined political centralization at the federal and provincial levels with a legitimization strategy that instituted electoral representation only at the local level Political centralization was achieved during the early years (1977-85) of the regime through the imposition of Martial Law, which held the 1973

\footnotetext{
${ }^{10}$ In the 1965 Presidential election, Ayub secured most of his votes from rural areas while urban areas mostly went against him because Ayub’s local government system placed rural representatives in a majority (Rizvi 1974).

11 "The Rural Works Programme had been evolved in 1961 to utilize the concealed unemployment in the agricultural sector through the institutions of Basic Democracies” (Amjad and Ahmed 1984).

${ }^{12}$ Urban population grew at a rate of approximately 5\% during this period. The ratio of urban to rural growth varied between 3.0 to 1.5 during the fifties and sixties respectively (Arif and Ibrahim 1998).

${ }^{13}$ Zulfiqar Ali Bhutto was one of the founder members of the Pakistan People's Party and held power as the head of state and Prime Minister between 1971-77.
} 
Constitution in abeyance, and was followed in 1985 by the $8^{\text {th }}$ Constitutional Amendment that established indirect military rule through a quasi-Presidential form of government (Noman 1988). Local governments were revived through the promulgation of Local government ordinances (LGOs) and local bodies were elected in all four provinces during 1979 and 1980. In essence, the army sought to use its old strategy of 'divide and rule' by creating a new and competing class of ‘collaborative’ local-level politicians (Jalal 1995).

However, the increased political importance of local bodies was not complemented by any further decentralization of federal or provincial administrative functions or financial powers to the local level. Cheema and Mohmand's (2003) comparison of LGO (1979) with BDO (1959) and the Municipal Administration Ordinance (MAO) (1960) shows that there was little change in the functions and financial powers assigned to local governments during the Zia and Ayub periods. Therefore, the increased importance of local governments as a means of political legitimacy did not translate into their substantive empowerment during either the Ayub or Zia periods. In fact, local governments continued to lack constitutional protection and their creation and maintenance remained at the whim of the provinces. Furthermore, Zia's local government legislation retained suspension powers in the hands of the provincial government, which could "prohibit the doing of anything proposed to be done" (Section 156(c))! During the early Zia period this meant that the military had significant control over local governments as military officers appointed as provincial governors headed the administration of provinces.

In spite of these differences Zia's LGO (1979) differed from Ayub's BDO (1959) in certain important respects. Zia consciously adopted populist measures introduced by Bhutto's unimplemented Local Government legislations (1972 and 1975), which abolished the direct representation of the bureaucracy in local governments as members and chairmen, and instead stipulated that all members (including chairmen) of all tiers of local government were to be directly elected through adult franchise (Sections 12 and 13 of LGO 1979) ${ }^{14}$. This was a significant change from BDO (1959) and MAO (1960). Although, the provincial administration retained suspension powers and the powers to quash resolutions and proceedings during the Zia period, nonetheless, their control over local government functioning through direct representation was loosened. "The

\footnotetext{
${ }^{14}$ We would like to thank Mr. Reza Ali for bringing this point to our notice.
} 
adoption of the representative principle clearly reflects a change in the model of local governance with 'greater autonomy' being given to elected representatives at the local level” (Cheema and Mohmand 2003). This was perhaps a circumscribed response to the emergence of mass-based politics during the sixties and seventies.

However, the unequivocal adoption of the representative principle was significantly weakened as Zia retained the historical principle of holding local elections on a non-party basis. Although, nonparty local level elections had been the general principle in areas that comprise Pakistan since the colonial period, nonetheless, the adoption of this principle by Zia ul Haq represented an important reversal because mass-based political parties had emerged as important players in the electoral arena since the 1970 federal and provincial elections. Zia retained this principle in order to neutralize the influence of political parties at the local level. Moreover, electoral competition was significantly weakened when the army disqualified a large number of candidates with a PPP affiliation in 1979 (Waseem 1994). Historical evidence suggests that these measures resulted in the localization and personalization of politics at the local level (Wilder 1999).

Another continuity between Zia's legislation and the British and Ayub legislations is the continued adoption of a rural-urban divide at the level of rural or district councils, town and municipal committees and corporations (see Fig. II.1). In addition, Zia ul Haq abolished the district (rural) councils' function of rural-urban coordination, which made the district council only responsible for governance in rural areas. However, increased urbanization, the growing size of urban markets, the heightened flow of rural goods into urban areas and the selected adoption of tax farming (AERC 1990) resulted in a significant increase in the per capita income of urban local councils ${ }^{15}$ as octroi ${ }^{16}$ and UIPT revenues started to increase in response to these socio-demographic changes and this trend continued well into the nineties (Cheema and Mohmand 2003, Tables I.1). However, the Zia regime consciously persisted with the rural-urban divide, which meant that the urban councils did not need to share the benefits from this increase in their per capita incomes with their rural

\footnotetext{
${ }^{15}$ During the Zia regime an area was classified as urban (as given in the 1981 Census) if it had the administrative status of Municipal Corporation, municipal or town committee or cantonment board regardless of its population size. This was a departure from the previous system which combined the administrative criterion with a population criterion and gave census commissioners discretion to declare an area urban if they felt it had "urban characteristics" (Ali 2002). Therefore, our use of the term "urban" implies administered urban areas.

${ }^{16}$ Octroi was a tax on goods imported into municipal limits for production or consumption. Before it was abolished by the federal government in 1999/2000, octroi had been the biggest source of revenue for urban councils, contributing on average 50-60\% of these councils' income. In Punjab and Sindh the Octroi was biased in favour of larger urban councils (Nasim 1999, World Bank 2000).
} 
hinterland $^{17}$. Historical evidence suggests that during the early part of his regime, Zia sought to accommodate the interests of the urban middle classes ${ }^{18}$ who had formed the core of the anti-PPP PNA movement ${ }^{19}$ and it appears that the decision to retain the urban-rural divide, at a time when urban local council incomes were increasing, allowed the state to accommodate strong anti-Bhutto urban middle class political mobilizations by giving them control, albeit circumscribed, over funds that could be used for the entrenchment of localized clientelist networks. As opposed to this the absence of buoyant sources of revenue in the hands of rural local councils meant that their capacity to deliver on even their meagre compulsory functions remained limited ${ }^{20}$. The precarious revenue situation of rural local councils combined with a legislative rule that denied rural areas access to urban revenues resulted in these areas becoming increasingly dependent on the provincial tier for service delivery.

Table I.1: Income Per Capita by Type of Council

\begin{tabular}{|c|c|c|c|c|}
\hline & \multicolumn{4}{|l|}{ Income Per Capita } \\
\hline & \multicolumn{3}{|c|}{ Urban Councils } & Rural Council \\
\hline & Municipal Corp. & Municipal Committee & Town Committee & District Council \\
\hline \multicolumn{5}{|l|}{1985} \\
\hline Punjab & 131.7 & 147.9 & 126.0 & 16.5 \\
\hline Sindh & 239.0 & 150.4 & 147.3 & 21.8 \\
\hline NWFP & 109.1 & 140.1 & 113.5 & 14.5 \\
\hline Balochistan & 187.4 & 146.2 & 249.1 & 0.3 \\
\hline \multicolumn{5}{|l|}{1990} \\
\hline Punjab & 327.9 & 187.3 & 135.0 & 21.4 \\
\hline \multicolumn{5}{|l|}{1995} \\
\hline Punjab & 282.3 & 290.4 & 176.5 & 45.7 \\
\hline
\end{tabular}

Source: AERC (1990), World Bank (2000), Population Census (1981, 1998)

Moreover, not surprisingly, this bias in income generation also resulted in unequal local expenditures skewed heavily towards the urban areas (Table I.2). This was a result of de jure

\footnotetext{
${ }^{17}$ For example, in the Punjab the average per capita octroi receipts for urban local councils were Rs. 74.5 in 1985 . In the absence of the urban-rural divide the per capita octroi revenue for rural and urban areas would have fallen to a meager Rs. 19 (AERC 1990).

${ }^{18}$ For example, Wilder (1999). Hasan (2002) argues that the increasing importance of urban middle classes in Punjabi politics, during the seventies and eighties, is underpinned by socio-economic changes that made agriculturalists dependent on mandi (market) arhtis (middlemen) and their transporters who controlled credit as well as the access to mandis with the connivance of the bureaucracy.

${ }^{19}$ The anti-Bhutto coalition in 1977 included: middlemen; traders and shop keepers from Punjab’s mandi (market) towns; small and large industrialists; and urban professionals (Noman 1988, Wilder 1999). For details see Cheema and Mohmand (2003).

${ }^{20}$ This situation was somewhat rectified post 1990 because more items were placed on the District (export) Tax list during the eighties and because of the adoption of tax farming for collection purposes (AERC 1990). This is shown by Table I.1, which shows a narrowing of the gap between rural council and urban council per capita incomes in the Punjab during the 1990-95 period.
} 
restrictions imposed on local government borrowing and because of the paucity of provincial transfers in favour of rural local councils.

Table I.2: Per Capita Expenditure by Type of Local Council

\begin{tabular}{|c|c|c|c|c|c|c|c|c|}
\hline & \multicolumn{3}{|c|}{ Recurring Expenditure Per Capita (Rs.) } & \multicolumn{3}{c|}{ Development Expenditure Per Capita (Rs.) } \\
\hline & \multicolumn{3}{|c|}{ Urban Councils } & Rural Council & \multicolumn{3}{c|}{ Urban Councils } & Rural Council \\
\hline Province & $\begin{array}{c}\text { Municipal } \\
\text { Corp. }\end{array}$ & $\begin{array}{c}\text { Municipal } \\
\text { Committee }\end{array}$ & $\begin{array}{c}\text { Town } \\
\text { Committee }\end{array}$ & $\begin{array}{c}\text { District } \\
\text { Councils }\end{array}$ & $\begin{array}{c}\text { Munici } \\
\text { pal } \\
\text { Corp. }\end{array}$ & $\begin{array}{c}\text { Municipal } \\
\text { Committee }\end{array}$ & $\begin{array}{c}\text { Town } \\
\text { Committee }\end{array}$ & $\begin{array}{c}\text { District } \\
\text { Councils } \\
\text { 1985-86 }\end{array}$ \\
\hline Punjab & 77.8 & 86.1 & 63.2 & 8.4 & 37.1 & 48.1 & 35.8 & 6.9 \\
\hline Sindh & 98.1 & 110.7 & 92.2 & 15.0 & 109.7 & 9.2 & 8.1 & 2.4 \\
\hline NWFP & 62.5 & 97.1 & 76.1 & 7.5 & 39.1 & 33.4 & 36.8 & 6.1 \\
\hline Baluch. & 71.1 & 103.6 & 337.1 & 3.1 & 9.4 & 37.6 & 2.6 & 0.1 \\
\hline $\mathbf{1 9 8 9 - 9 0}$ & & & & & & & & \\
\hline Punjab & 78.5 & 102.5 & 74.0 & 7.9 & 117.1 & 88.3 & 59.0 & 10.2 \\
\hline $\mathbf{1 9 9 4 - 9 5}$ & & & & & & & & \\
\hline Punjab & 134.8 & 184.1 & 117.7 & 17.5 & 134.5 & 99.2 & 55.6 & 26.0 \\
\hline
\end{tabular}

Source: AERC (1990), World Bank (2000), Population Census (1981, 1998)

These changes helped consolidate urban political parties, such as the MQM in Sindh and the Nawaz Sharif faction of the Muslim League in Punjab, with the latter being elevated to prominence in provincial politics during the Zia regime. The accommodation of urban middle class interests continued after the revival of elected federal and provincial governments as there was a steady consolidation of Punjab’s urban middle class vote in favour of Nawaz Sharif's Muslim League. ${ }^{21}$ The political and economic consolidation of Punjabi urban middle class groups was facilitated by increased remittances from migrant Punjabi workers in the Gulf (Addleton 1992, Zaidi 1993) and due to fast rates of urbanization, which counterbalanced rural Punjab’s numerical majority. However, the increasing political importance of urban middle class groups was considerably offset by the revival of elected Assemblies in 1985, which overrepresented rural politicians in the provincial and Federal parliaments because of the numerical strength of the rural majority and enabled them to negotiate development payoffs ${ }^{22}$ through the Provincial and Federal tiers. $^{23}$

Evolution of the Local Government Structure 1985-1999: The revival of elected provincial and Federal governments in 1985 reinforced the localization of politics that had begun with the 1979

\footnotetext{
${ }^{21}$ PML (N)'s support in urban constituencies increased from 33\% in 1988, to 53.9\% in 1993. Furthermore, PML (N)'s electoral performance was equally strong in large, medium and small-sized urban areas (Wilder 1999).

${ }^{22}$ Such payoffs include Prime Minister Junejo’s 5 point programme and Benazir Bhutto’s People’s Works Programme.

${ }^{23}$ Given this qualification it is not clear whether there is an urban-bias in the aggregate development allocations. It could be the case that Provincial and Federal payoffs for rural areas more than offset the urban-bias in local government allocations. However, this hypothesis remains untested because data on provincial allocations by rural and urban areas is not available pre-2001.
} 
local bodies' elections. The dominance of these revived assemblies by local bodies' politicians ${ }^{24}$ helped transplant the culture of local body politics to the provincial and national levels (Wilder 1999). This tendency was reinforced by the non-party nature of the 1985 assemblies and governments, which 'personalized patronage ${ }^{, 25}$ as elected government ministers began to use development funds to increase their individual chances of reelection. ${ }^{26}$ Moreover this personalization of politics did not reverse despite the revival of party-based Federal and Provincial Assemblies and governments in 1988. The persistence of this tendency is partly an outcome of weakening party organizations, which is due to adverse de jure and de facto measures instituted by the Bhutto and Zia regimes (Wilder 1999). As a result the allocation of party tickets and ministries is more an outcome of individual bargaining between powerful local brokers and party leaders rather than being based on collective decision making within the political party organizations as borne out by the extensive switching of candidates between political parties that has taken place since 1985.

Furthermore, the absence of political linkages between different tiers of government, which was an outcome of the non-party basis for politics, created tensions between provincial and local politicians with the local tier being viewed as a competing structure of 'patronage' (Wilder 1999). The 'tension' between the province and local governments was exacerbated because of the federal government's encroachment upon provincial functions, which was seen as a way to weaken the purview of the provinces (World Bank 2000). This created a lack of 'political ownership' with regard to the local tier that resulted in a number of serious consequences. 'Discretionary' special development programmes became widespread at the higher tiers and became an effective means for federal and provincial politicians to obtain unaudited control over local level development allocations (AERC 1990, Nasim 1999, World Bank 2000). Moreover, the concentration of buoyant revenues in the hands of the Federal and provincial governments ${ }^{27}$ constrained the financial capacity of local governments prompting the Provinces to play an ever increasing role in service provision,

\footnotetext{
${ }^{24}$ For example nearly 50\% of the elected members of the Punjab Provincial Assembly were sitting local councilors (Niazi 1994).

${ }^{25}$ The term personalized politics describes the tendency among powerful ministers to use state resources to capture influential: party-, biradari- (community), quam- (tribe or nation) and/or zat (caste) based local factions.

${ }^{26}$ As one minister put it during the 1985 National Assembly’s first budget session, "We don't have one party, or ten parties....; we have two hundred parties. Each member of the assembly considers himself responsible only to himself (Haq 1985).

${ }^{27}$ Over 96\% of Pakistan's revenue was controlled by the Federal and Provincial governments in the last two decades (World Bank 2000).
} 
especially post $1990^{28}$. Finally, this tension between provincial and local tiers resulted in the suspension of local bodies between 1993 and 1998 and as before, in the period immediately following independence, somewhat paradoxically it was democratic forces at the provincial and higher levels that pushed for a retrenchment of local governments.

The eighties also differed from earlier periods in that instead of a dominant role, they saw the bureaucracy emerging as junior partners in their alliance with the military over state control. The bureaucracy had already been weakened by Bhutto's Civil Service Reforms in 1973 that amalgamated the elite CSP cadre into a hierarchical and mobile framework of 22 pay scales, which ended its exclusive elite status (Cheema and Sayeed 2004). Despite radical and wide-ranging recommendations from the Civil Services Reform Commission, Zia chose to strengthen this statusquo and did not consolidate the institutional strength of the civil bureaucracy. Although the military's reliance on the bureaucracy as junior partners arrested the declining trend, nonetheless, some of the measures taken further weakened the bureaucracy like the increase in the induction of military officers into the services. Furthermore, the authority of the bureaucracy was weakened through the widespread use of political control to horizontally and vertically transfer bureaucrats across cadres (World Bank 1999). This became an important mechanism for shedding bureaucrats who refused to play ball, and was used by not only the army but also by subsequent political governments. Moreover, a relatively free hand in recruitment to new jobs turned ministries and departments into virtual employment agencies and almost doubled the number of civil servants between 1977 and 1987 (Waseem 1994).

Finally, it is worth noting that the revival of party-based elected political governments in 1988 did not reverse the earlier trend towards centralization of fiscal power and political control. In our view, the incentive to concentrate political control in the central executive was strengthened by a number of factors. Primary among them was one party’s lack of dominance in electoral politics at both the centre and at the level of the provinces. ${ }^{29}$ Centralization of political power was also seen as a way of redressing the indirect control of the military in politics ${ }^{30}$, which persisted by virtue of the 8th

\footnotetext{
${ }^{28}$ Data shows that the ratio of municipal corporation per capita income (the richest tier of local governments) to provincial per capita income decreased from 0.78 in 1990 to 0.32 in 1995.

${ }^{29}$ The 1997 elections was the only exception and can be better explained by the second factor discussed in the text.

${ }^{30}$ An important example of this tendency was Nawaz Sharif's attempt to revoke important provisions of the 8th Constitutional Amendment during his second term as Prime Minister.
} 
Constitutional Amendment ${ }^{31}$ instituted by the Zia regime. Finally, the frequent exercise of dissolution powers by various Presidents shortened the time horizons of the political leadership at the centre, which created added incentives for the centralization of budgetary funds. As a result of these factors expenditure functions continued to be centralized due to which the actual distribution of federal government functions has diverged considerably from the legislative distribution (World Bank 2000).

\section{The New Devolution of Power Plan}

This section gives an overview of the current decentralization process introduced as the "Devolution of power” plan by General Pervaiz Musharraf in January 2000 and implemented after a series of local government elections that ended by August 2001.

There are several aspects of the reform that are worth highlighting in this section. First of all, in addition to devolving administrative and expenditure responsibilities to local governments, the decentralization involved, to differing degrees, changes in the administrative level of decision making, the accountability of the decision making authority (political or bureaucratic) and the nature and amount of fiscal resources available. ${ }^{32}$ Secondly, the decentralization process was not uniform across all functions, with significant heterogeneity in its extent not only across different administrative departments but often also across different services within a department. Finally, the reform took place fairly rapidly and under military rule and hence at the time when no provincial and federal elected governments were in power. As a result its implementation is still in a process of flux and is undergoing changes even as this note is being written. While one can foresee some of these changes, a note of caution needs to be raised in taking any description of the current decentralization as final.

\section{Overview:}

With this caveat in mind we start with a very stylized description of the devolution plan. In a nutshell, the devolution process substantially restructured the sub-provincial (district and below) government structure. Whereas previous locally elected governments did exist at this level, their powers were fairly limited and most of the functions were carried out by provincial line

\footnotetext{
${ }^{31}$ Amendments to articles 58 and 48 of the 1973 Constitution established a quasi-Presidential form of government in 1985.

${ }^{32}$ These reforms were brought about through a new local government ordinance, a new Police Order (2002) and abolition of executive magistracy through amendments in relevant laws.
} 
departments, a deconcentrated bureaucratic tier that did not report directly to provincial elected representatives. Under devolution, a new elected government was created at the district level and politically linked to local governments at the sub-district levels (Tehsil and union council). ${ }^{33}$ The district government is headed by an elected nazim (Mayor) and the district administration head, the District Coordination Officer (DCO) reports directly to the elected head of the government. This is a significant departure from the previous system where the de facto head of the district administration, the Deputy Commissioner (DC), reported to the non-elected provincial secretariat. Moreover, the office of the DC has been abolished and the new head of district administration, the DCO, is no longer the district magistrate or the district collector. ${ }^{34}$

Figures II.1 and II.2 provide an illustration of these changes. For purposes of simplicity, the figures present a stylized diagram of the administrative structure only indicating the administrative levels and whether the primary functionaries at these levels were bureaucrats (B) and/or elected representatives (E). Using these figures we now highlight the major changes brought about by the current devolution plan:

- Greater presence and scope of elected government at local level: While local governments did exist in periods prior to devolution, they did not have any significant role as these local governments, especially in rural areas, were practically inactive ${ }^{35}$ and more importantly, most of the state functions were carried out by the provincial bureaucracy (the left side of Figure II.1). As is clear from the figures, post-devolution, the elected government and provincial administration have been integrated at the district and Tehsil levels, the division abolished altogether and the local level provincial administration has been made accountable to elected officials at the local level. Additionally, the vast majority of public services that were previously under the local provincial administration, have been transferred to the local governments, substantially increasing their scope and responsibilities.

- Limited Financial decentralization: While the scope of local governments in terms of the services they are responsible for and how they allocate district level expenditures across services

\footnotetext{
33 The new system has established political linkages between the three tiers of local governments by making union nazims (mayors) and naib nazims (deputy mayors) members of district and Tehsil councils, respectively. However, LGO (2001) has not stipulated any formal administrative linkages between these tiers.

${ }^{34}$ Specifically of the DCs functions of executive magistracy, revenue collection, and general administration cum coordination, the DCO has only retained the last, general administration cum coordination.

${ }^{35}$ Even these limited local governments were mostly suspended during the 1990s so in fact prior to the current devolution there were no elected representatives at the local level and their powers were exercised by provincial bureaucrats as local government administrators.
} 
increased substantially post-devolution (see Figure II.3), the extent of financial decentralization is limited both because (i) districts governments continue to have the same limited revenue collection abilities (no new taxes have been devolved to the district and tehsil levels) and still rely primarily on provincial and ultimately federal funds, through the provincial finance commission awards ${ }^{36}$ (although the latter has been made rule-based - see section III below) and (ii) a significant majority of district expenditures are "establishment charges" which, while incurred by the district, cannot be altered by the district; these expenditures include salaries of administrative personnel who continue to be provincial employees and as such the district cannot fire them or adjust their wages.

- Provincial to Local decentralization with no Federal decentralization: What is not apparent from the figures is that decentralization essentially involved a transfer of provincial powers and responsibilities to the district and lower levels of governments but interestingly enough, no decentralization of any federal powers to either the provincial or local levels. ${ }^{37}$

- Uneasy integration between Provincial/Federal and District level elected governments: Whereas prior to devolution, there was no significant link between the elected provincial/federal and the local governments, it did not matter since most of the state services were provided through the provincial administration which was indirectly responsible to the provincial elected representatives. However, post-devolution, the elected local government was transferred a large proportion of these services. Given that the devolution process took place at a time when there was no provincial/federal elected government and the local government elections were held on a non-party basis, no effort was made to integrate the newly elected local government with the soon to be elected provincial/federal governments. This has resulted in an interesting but not so surprising conflict between the local and provincial/federal elected representatives which we will address more explicitly in the next section.

- Integration of Rural and Urban areas: During the pre-devolution period there was a sharp and (financially) important distinction between urban and rural local governments. However, post-devolution as is apparent in the figures, this distinction is no longer there. As we will show

\footnotetext{
${ }^{36}$ Provincial governments are heavily dependent on federal transfers, which constitute approximately $80 \%$ of total provincial revenue (World Bank 2000).

${ }^{37}$ The National Reconstruction Bureau established the Higher Government Restructuring Committee in 2001 to suggest devolution of powers from the Federal to the Provincial level. However, no concrete steps have been taken on this front as of today.
} 
in Section III, this change is important in terms of the amount of resources flowing from urban to rural areas.

- Changed local electoral processes: Prior to devolution, members of urban local councils and district councils were directly elected, and then they elected the heads of their respective councils. Under devolution, both the members and heads of the lowest level of government, the union council, are elected through public vote as before. However, interestingly enough the new legislation has created inter-governmental political linkages by ensuring that the majority (twothirds) of the members of the Tehsil and district councils are these elected heads. The remaining one-third members of district and tehsil councils and the heads of district and tehsil governments are elected indirectly by the directly elected union-council members. Thus in particular, the head of the district government, the District Nazim, need not command a majority of the public vote in a district but rather a majority of the union councilors and union nazims elected in the district (see Appendix B for details). Another important electoral change has been a significant increase in reservation for peasants and women with a total of one-third seats reserved for both as compared to $5 \%$ and $10 \%$ in the district councils previously.

- Limited Constitutional Support: Despite the new local government structure Pakistan is constitutionally still a two-level federal state i.e. the local governments are not recognized as the third tier of government by the 1973 Constitution. The $17^{\text {th }}$ Constitutional Amendment provides limited protection to the local governments for a period of only six years during which provinces can make changes to the local government legislation with the concurrence of the President.

- Heterogeneity in the Extent of Decentralization: What is also not apparent in these figures is that the decentralization process was not carried out uniformly either across all administrative departments and more importantly, across services within a given department. Specifically, while most provincial service departments were devolved some important services like the Police $^{38}$ and irrigation departments were retained by the Province. However, even within the devolved departments, as hinted above, not all functions were devolved and certain activities, judged to be those with greater economies of scale, remain within the provincial purview. We provide a closer look at these changes and differences below.

\footnotetext{
${ }^{38}$ Whereas the district police has been made responsible to the District Nazim under the Police Order 2002, the investigative, prosecution and administrative functions of the district police do not fall under the purview of the district government.
} 


\section{Characterizing Devolution:}

While the previous overview provides an illustration of the changes brought about through the current decentralization process, it misses some of the interesting details. In this section we elaborate on some of these aspects and offer a more detailed characterization of the changes.

Since the primary goal of a state is to provide public goods and services to its constituents, we argue that a useful way to categorize the devolution process is in terms of the changes in administrative level, accountability, and fiscal resources available to these services. To this end we carried out a detailed exercise of mapping out the extent of devolution, at least as envisaged on paper, under the local government ordinances. Moreover, for select departments this mapping was tallied with actual practice by conducting detailed interviews with members of these departments. While presenting the details of this mapping is beyond the scope of the current note, we will use examples from this exercise to illustrate the type of changes brought about by devolution and the heterogeneity in these changes both across and within different departments.

Specifically we will focus on three types of changes:

I. Changes in the decision-making level of the service: A particular service that was decided at the provincial level by bureaucrats but after devolution it is decided by the district-level bureaucracy. Similarly a service that was under the purview of provincial level elected representatives before devolution, and has been transferred to the district-level elected representative post-devolution. Note that these instances only involve a change in the decision-making level but not in the accountability (bureaucratic or elected) of the decision maker.

II. Changes in the decision-maker accountability: A particular service that was decided at the district level by bureaucrats but after devolution, while it is still decided at the district-level (i.e. there is no level change in decision-making), the decision making authority is now an elected district representative and hence the accountability of this service has a more direct link with the voting public.

III. Changes in the fiscal resources available to the service: While there are no significant changes that directly affect how much funds get allocated to a particular service, there may be an indirect effect on the service in a local area due to changes in how a particular local area (i.e. districts, tehsils) receives funds through the Provincial Finance Commission (PFC) 
award and due to the elimination of the urban-rural distinction in local governance and taxation.

Below we provide explicit instances of these changes:

\section{Level Changes}

These are changes where a particular service is still decided by a similar agent (bureaucrat or politician) but at a different level in the government hierarchy as compared to before. While theoretically all types of changes are possible, devolution has primarily involved the following:

A. Province to Province: For the sake of completeness we start with instances where there has been no change in the administrative level. This can happen either because:

i. An entire department is not devolved. Examples include departments like the Irrigation and Police have not been devolved at all. The Irrigation department has not been devolved because of significant interjurisdictional spillovers associated with this service and the police, in order to maintain uniformity of this service across the districts in a province.

ii. Certain activities in a department have been retained at the provincial level. For example university education has remained a provincial subject despite most of the remaining educational services having been devolved to the district level. Similarly, administration of teaching hospitals (Health department), agricultural research and development (Agriculture department), supervision of foreign funded projects (Planning and Development department) and regulation of medical standards (Health department) have remained at the provincial level despite the devolution of other activities in these departments.

iii. Certain budgetary heads of expenditures have effectively been retained at the provincial level. The most important example is salary and allowance expenditures of all department employees. Since most employees in the administrative departments remain provincial employees, the district cannot create or reduce posts or adjust their salary structure and therefore, a large fraction of the district budget is fixed. ${ }^{39}$ Thus for departments where a large fraction of the current expenditure incurred is on salaries, such as the Education department which spends around $90 \%$ of its non-development budget on salaries, this is a significant factor limiting the extent of decentralization.

\footnotetext{
${ }^{39}$ In the Punjab, district governments are empowered to create contractual posts provided they fund them from own source revenues and are able to obtain the "concurrence” of the provincial finance department.
} 
B. Province to District: This is the most common and significant change whereby the budgeting, planning and development functions related to services that were previously decided at the provincial level have now been devolved to the district. The Education department, the largest expenditure head of the provinces, has experienced such a change in its major functions. Since a large part of these activities were decided at the provincial level before, this has entailed devolution of administrative level i.e. before these decisions were based primarily on the Provincial Secretariat (B) and the Provincial Cabinet (E). Now the analogous decision-makers are at the district - the District Nazim (E), the Executive District Officer Finance and Planning (B) and the Executive District officer Education (B). Similarly, most of the other departments have experienced a similar move to the district level. For example, activities such as those pertaining to primary health care and management of district and Tehsil hospitals (Health department), assessment and collection of land taxes, cesses and agricultural income tax (Revenue department), agricultural extension and farm water management (Agriculture department), planning and design of district roads and buildings (Communication \& Works department) are now devolved to the district governments from the province.

C. Province to Tehsil: Services provided by the Local Government and Rural Development department and the Housing, Urban Development and Public Health Engineering department have been devolved from the Provincial to the Tehsil level. The devolution of these departments has ensured that the provision of municipal services is now the sole functional responsibility of the Tehsil Municipal Administration. This is a change from the previous system, where these services were simultaneously provided by both the rural and urban local councils and by the provincial line departments.

The next two level changes are unusual for a decentralization program in that they represent spatial and functional integration at the Tehsil and district levels:

D. Urban/Rural Local Council to Tehsil: Several of the services that were previously the domain of urban or rural local councils have been spatially and functionally integrated at the Tehsil level. Among others, these include key municipal services such as water supply, sewerage, sanitation, drainage schemes and street lights.

E. Urban/Rural Local Council to District: To a somewhat lesser extent, there are services that have been centralized even further to the district government level. Services such as the establishment of new schools, up gradation of existing schools, and the maintenance and 
inspection of schools that were under the local councils are now the responsibility of the district governments. Other examples are dispensaries and hospitals run by the old local councils. However, it must be emphasized that these services constitute a small fraction of the overall provision of similar services made by the District Government.

It is worth emphasizing again that there are no instances whatsoever of decentralizing a service from the federal to any lower level rather, as apparent above, the devolution has been of provincial services to the district or lower levels.

\section{Accountability Changes}

These are changes where a particular service is now decided by an agent who differs in his accountability to the public. In particular, devolution brought such an accountability change primarily at the district level. Whereas prior to devolution, the deconcentrated provincial bureaucracy at the district level was accountable to their non-elected provincial secretariat, under the present system they are accountable to the elected heads of district and Tehsil governments. Rather than going through a similar illustration of which services underwent such a change, it is sufficient to state that any service that was under the purview of district officer of a provincial line department and is now placed under the district government, effectively underwent such an accountability change i.e. the ultimate decision maker changed from a provincial government district officer who reported to the provincial bureaucracy, to an elected Nazim who ultimately is answerable to his district's constituents.

The most significant accountability change is that the de facto head of district administration under the previous system, the deputy commissioner (DC), used to report to the non-elected provincial bureaucracy, whereas in the present system the head of the district administration, the District Coordination Officer (DCO) reports to the elected district nazim. Although it needs to be pointed out that the authority of the Nazim over the DCO and Executive District Officers (EDO) is circumscribed in matters of transfers and promotions, which continue to remain under the purview of the provincial secretariat, and as a result this accountability change remains circumscribed in both a de jure and a de facto sense.

\section{Financial Changes}

There have been fiscal changes that have accompanied the devolution process that, while not necessarily directly affecting the allocation of funds to a particular service, are likely to have an 
indirect effect on such allocations in so far as they change the total amount of funds available to each local government.

Changes in budgetary transfers - Non-discretionary and non-lapsable: A significant financial change accompanying decentralization has been the establishment of a 'rule-based' fiscal transfer system between the provinces and the local governments. Previous local government reforms failed to establish an adequate fiscal transfer system with the result that local councils were unable to perform even the limited expenditure functions assigned to them (Hyder 1999). The nondiscretionary intergovernmental fiscal transfer process is determined by the "Provincial Finance Commission” awards. The interim awards for 2002-03 have devolved approximately 40\% of the Provincial Consolidated Fund as the Provincial Allocable Amount for distribution among local governments (see Table II.1) in order to ensure the maintenance of at least the current level of district recurring expenditures. Barring Balochistan, all interim awards have given weightage to backwardness in order to ensure some form of equity across districts in the allocation of development funds. ${ }^{40}$ Moreover, in addition to this non-discretionary aspect, these budgetary transfers have also changed in that they are no longer lapsable and continue to be retained by the relevant local governments. It should be noted though that while the interim PFC awards have established a rule-based transfer mechanism for the distribution of the Provincial Allocable Amount between local governments, the Provincial Finance Commissions are yet to establish well defined 'rules' for the division of the Provincial Consolidated Fund between the Province and the local governments even though this is required by the legislation.

Table II.1 Provincial Finance Awards (2002-03)

\begin{tabular}{|c|c|c|c|c|}
\hline Total pool and distribution criteria & Punjab & Sindh & NWFP & Balochistan \\
\hline Local share of the Provincial Divisible Pool & $\mathbf{3 9 . 8} \%$ & $\mathbf{4 0 \%}$ & $\mathbf{4 0 \%}$ & $\mathbf{3 1 \%}$ \\
\hline Formula factors with weights: & $\mathbf{1 0 0 \%}$ & $\mathbf{1 0 0 \%}$ & $\mathbf{1 0 0 \%}$ & $\mathbf{1 0 0 \%}$ \\
\hline Population & $\mathbf{7 5 \%}$ & $\mathbf{5 0 \%}$ & $\mathbf{5 0 \%}$ & $\mathbf{5 0 \%}$ \\
\hline Backwardness & $\mathbf{1 0 \%}$ & $\mathbf{1 7 . 5 \%}$ & $\mathbf{2 5 \%}$ & - \\
\hline Tax Effort & $\mathbf{5 \%}$ & $\mathbf{7 . 5 \%}$ & - & - \\
\hline Fiscal Austerity & $\mathbf{5 \%}$ & - & - & - \\
\hline Area & - & - & - & $\mathbf{5 0 \%}$ \\
\hline Development incentive/infrastructure deficiency & $\mathbf{5 \%}$ & - & $\mathbf{2 5 \%}$ & - \\
\hline Transitional assistance & - & $\mathbf{2 5 \%}$ & - & - \\
\hline
\end{tabular}

Source: Manning et. al. (2003)

Urban-Rural reunification: The integration of urban and rural administrative areas (at the Tehsil level) also has significant implications on the flow of funds between urban and rural areas. In

${ }^{40}$ Although it is unclear what type of index has been used to measure backwardness. 
particular, until 1999 a major source of revenue for the urban areas was octroi levied in urban areas

for all goods regardless of whether they were eventually consumed in a rural $\mathrm{area}^{41}$. This resulted in a disproportionate access of resources for urban areas. After devolution, however, there is no longer any rural-urban distinction as both such areas within a tehsil fall under the jurisdiction of the same tehsil government. In such a case, the resources for both such areas for a given Tehsil are pooled and, in the likely situation that the rural area has greater voting importance, one may expect to see a correction of the urban bias in funding and perhaps even a bias towards the rural areas. This issue is addressed in detail in section III.

\section{The Political Economy of Decentralization}

The purpose of the first section, other than presenting a history and context of decentralization in Pakistan, was to help shed light on the political economy of decentralization, particularly for the most recent reforms under General Musharraf. In this section we recap some of the salient trends identified in the previous sections in order to better understand why centralized regimes are seemingly willing to shed their own powers. Our contention is that the recent devolution, while more ambitious and broader in scope than previous attempts, is in several important ways a natural continuation of previous decentralization attempts and is best understood in light of this context.

\section{A. Non-Representative Centres and Local Government Reforms}

The central tendency revealed by our historical analysis is that local governments have been enacted by non-representative regimes to legitimize their control over the state. Legitimacy has been sought by creating a localized patronage structure that produces a class of 'collaborative politicians' who act as a conduit between local level constituencies and the non-representative centre. This is as true of the British period as it is of the post-independence period. The difference between these periods lies in the nature of the non-representative institution that established its authority over the state. In the pre-independence period it was the British imperial state that introduced modern local self government. In the post-independence period it has been the Pakistani military.

Musharraf's local government reforms represent a continuity of this central historical tendency. Unlike attempts at decentralization in some other countries, which appear to have been motivated

\footnotetext{
${ }^{41}$ Octroi and Zila tax were abolished in 1999.
} 
more by changes in state ideology or multilateral pressure, in Pakistan, the military's need for legitimization of state control appears to be a prime reason behind the recurring attempts at local government reform. Multilateral pressure for decentralization in Pakistan had existed since the midnineties (World Bank 1996, 1998); however, no major attempts at decentralization were initiated by the Pakistani state until General Musharraf’s takeover in 1999.

A corollary to this central tendency is that local government empowerment has always been combined with centralization of political power in the hands of the non-representative centre. The centralization of political power has undermined representative institutions not only at the level of the centre but also at the level of the provinces. Each attempt at centralization of political power by the military during the post independence period has initially involved the dissolution of elected provincial and federal assemblies and has invariably been followed by the enactment of a presidential or a quasi-presidential constitution, which preserves the non-representative institution's role at the centre even after the revival of representative governments. Centralization of political power has also involved selective disqualification of political party representatives and at times outright bans on all or certain political parties. As a result, these attempts at centralization of political power have considerably weakened the organizational structure of political parties and have distorted electoral competition at the provincial and central levels.

The Musharraf regime represents another attempt at combining the empowerment of local governments with the centralization of political power through the establishment of a quasiPresidential constitution. General Musharraf's Legal Framework Order (2002) as enshrined in the $17^{\text {th }}$ Constitutional Amendment institutionalizes the role of the military in the centre by strengthening the powers of the President vis-à-vis the elected Prime Minister. ${ }^{42}$ The current attempt at centralization of political power by the military has again been accompanied by a number of interventions against politicians and political parties. These interventions include selective accountability and disqualification of politicians, the enactment of an educational criterion for electoral candidacy and the creation of a pro-military political party, the Pakistan Muslim League $(\mathrm{Q})$, which currently retains political power in the centre and in the Punjab.

\footnotetext{
${ }^{42}$ Substantive powers include the revival of article 58-2(b) which empowers the president to dissolve the elected assemblies.
} 


\section{B. "Limited" Local Governments}

While all non-representative governments have been the protagonists of local government reforms, they have not given complete autonomy to these governments by design. This is perhaps another manifestation of the desire of the non-representative centre to retain political control over local governments. Political control was directly exercised by the centre through the bureaucracy during the British and Ayub periods. Neither the British nor the Zia regimes gave constitutional cover to the local tier, which reflects the centre's lack of commitment to entrench an autonomous and selfsustaining local tier. In addition, during the Zia period local government reforms were designed to give suspension power to provincial military governors, which established a credible threat of removal over local politicians. ${ }^{43}$ This was perhaps a safeguard exercised by the non-representative centre against the emergence of a politically independent local tier.

Even the current regime has not constitutionally recognized local governments as a third tier of government. This is in contrast to India where the $73^{\text {rd }}$ and the $74^{\text {th }}$ constitutional amendments explicitly recognize local governments as the third tier of government. Nor has the current regime done away with the suspension powers granted to the higher tiers of government. ${ }^{44}$ These design choices may have potentially significant effects on the sustainability of the reforms especially as provincial ownership of the local tier remains weak (see the next section).

\section{Distortions and Conflicts in Politics- Local Governments versus the Province?}

Not surprisingly, given the central tendency identified above, non-representative designers of local government electoral processes have invariably placed a series of limitations on organized political representation, which has distorted electoral competition at the local level. The most extreme limitation was placed during the early British period when local government members were nominated by the centre, a rule designed to undermine local electoral competition. All military governments, including the current regime, have required local government elections to be held on a non-party basis. A likely objective of this measure has been to weaken the presence of opposition political parties at the local level. Under the Zia regime, successful candidates with a PPP affiliation

\footnotetext{
${ }^{43}$ For example see section 29 of Punjab LGO (1979).

${ }^{44}$ Section 23 of LGO (2001) empowers the provincial government to remove the Nazim through external recall through a simple majority in the provincial assembly. Furthermore, even the recent LFO agreement reached between General Musharraf and the political opposition only limits constitutional protection for local governments for a period of 6 years.
} 
were disqualified on different pretexts in the 1979 local bodies' elections (Wilder 1999). Similarly, recent press reports indicate that candidates with opposition party affiliations, who were successful in Southern Punjab and rural Sindh, were pressurized to withdraw their party affiliations. Opposition politicians have interpreted these interventions as a means to create a competing class of collaborative politicians and to weaken the base of political parties at the provincial level.

Historical evidence suggests that a consequence of Zia's non-party based local elections has been the reversal of a more universalistic basis of political organization, which had emerged with the ascendancy of the Pakistan People's Party (PPP) in the seventies, resulting in a localization of politics (Wilder 1999). Accompanying this localization has been a personalization of politics with local clientilistic elements introduced even at provincial level. While such patronage is to be expected in local politics where the politician is likely to be in direct and regular contact with his constituents, since Zia's subsequent provincial elections were based on promoting these same local politicians, local clientilist patronage also became an important element at higher levels of governance. Evidence of this was the introduction of special "development grants" awarded to members of provincial and national assemblies, whereby these politicians could and did deliver public goods at extremely localized levels in order to satisfy their supporters.

More significantly, the non-party basis of local government elections has invariably ended up weakening political linkages between elected provincial governments, which have tended to be party based, and local governments. Political parties, when in government at the provincial level, have tended to view local governments as a competing tier of 'patronage' (Wilder 1999) and as a result they have not made any attempt at empowering the local government system. If anything, they have tended to suspend and/or abolish established local governments when in power. Thus each elected government which has followed the military regimes that introduced local governments, has at the very least ignored these local governments and often suspended them altogether. This antagonistic relationship between local and provincial governments also arises because local government reforms are perceived as a way to weaken the authority and the delivery functions assigned to provincial politicians without a commensurate compensation in the form of devolution of powers and resources from the federal to the provincial level. In addition, since the current members of the provincial and national assemblies are, in a very large number of cases, a product of the 1979 non-party local elections they are more interested in organizing local level payoffs than pursuing legislative questions (Cheema and Mohmand 2003). 
These provincial-local government tensions have heightened during the current reform period. Among other reasons this is because no attempt was made to build political ownership of these reforms amongst elected provincial governments. This is in part because local government reforms, which represented a major reassignment of provincial functions and resources to the local tier, were enacted prior to the establishment of elected provincial governments. Local governments were again legally empowered in the absence of elected provincial governments, despite the fact that local government is a provincial subject under the 1973 constitution. Given this history and the fact that the powers, authorities and resources of elected Members of the Provincial Assemblies (MPAs) have been significantly curtailed by the current system, it is not surprising that there is poor ownership of the local government system amongst provinces. In fact, in Sindh and NWFP there have been open conflicts between the two tiers (Manning et. al. 2003), which have been managed through the intervention of the Federal government. Even in the Punjab, where the PML (Q) is in power, MPAs have not tendered widespread acceptance of the present system.

\section{The role of the Bureaucracy}

The historical analysis shows that there has been a change in the tendency of non-representative centres to use the bureaucracy to control local governments. Bureaucratic control over local governments was most explicit during the British and Ayub periods. The Zia regime circumscribed direct bureaucratic representation in local governments, which resulted in greater autonomy for the elected tier at the local level. The Musharraf regime has furthered this trend through two means: First, it has considerably weakened the provincial bureaucracy by reassigning a large proportion of their functions to elected local governments and by abolishing the office of the deputy commissioner. Second, and more importantly, are the accountability changes brought about by the present system whereby the provincial bureaucracy at the local level has been made accountable to the elected heads of district and Tehsil Municipal Administration. Therefore, in terms of Figure II.2 the (B) - (B) hierarchy for the provincial bureaucracy at the district level has been replaced in a de jure sense by an (E) - (B) hierarchy at the district and Tehsil levels. It needs to be pointed out that the weakening of the provincial bureaucracy is circumscribed as the provincial secretariats still retain considerable administrative authority over district bureaucrats (Manning et. al 2003), which at times has been used to trump the authority of the Nazim, even though the relative de jure bargaining power between the district bureaucracy and the Nazim has been tilted in favour of the latter. 
This weakening of bureaucratic control over local governments represents a significant departure from the earlier tradition where political support for the centre was harnessed through an alliance between the bureaucracy and powerful rural notables at the local level (van den Dungen 1972, Hasan 2002). The continuity of this alliance was dependent on the bureaucracy delivering patronage, administrative protection and protection of property rights in favour of the dominant elites in village society who, in turn, delivered political support and lack of political unrest for the centre. The ability of these elite to perform these functions depended upon their control over land and was institutionalized by the colonial and post-colonial state by according them a mediating role between the state and the village in revenue, civil and criminal matters (Hamid 1980, Hasan 2002, Rouse 1983). Rapid rates of urbanization, green revolution, industrialization and the rise of mass electoral politics during the sixties and seventies resulted in a breakdown of this social and political tradition. As a result of these changes, the factors that gave the local elite power expanded to include among other things their control over new sources of wealth, their ability to agglomerate electoral support and their ability to offer informal enforcement (Hasan 2002). More importantly, the power of the new local elites was no longer exclusively contingent on the support of the bureaucracy. This may have reduced the ability of the bureaucracy to harness political support for the centre and increased the ability of local politicians to deliver political support even in the absence of bureaucratic patronage. The failure of the traditional model is most evident in the failure of the bureaucracy-local elite nexus to defuse the Anti-Ayub mass political unrest during the late sixties and the defeat of state-backed local notables by PPP candidates during the 1970 elections.

Thus the weakening capacity of the district bureaucracy to deliver political support for the military and the increased organizational ability of local elites to harness political support is one likely explanation for why the military has chosen to abandon the bureaucratic control model and assign wide ranging functional responsibilities and resources in favour of locally elected politicians. ${ }^{45}$

\section{E. Rural -Urban Dynamics}

Our analysis shows the existence of a strong rural bias in central and provincial government policies during the British period in an effort to maintain social order among the majority rural population. We have also argued that Ayub in part reflected a similar rural bias by increasing the share of targeted provincial and federal development resources in favor of rural areas, which reversed the

\footnotetext{
${ }^{45}$ In fact, while the military has made the provincial district and service delivery bureaucracy more accountable, it has not created similar accountabilities for the Police, which remains out of the purview of the Devolution Plan.
} 
urban bias in the provision of these resources that had arisen during the fifties. This preference is not surprising given that the rural areas formed a majority in Ayub's Electoral College. However, while Zia ul Haq continued the rural-urban divide at the local level, interestingly in his period this meant a tilt in favor of urban areas as increasing urbanization during this time resulted in significant relative increases in per capita tax income of urban local councils as compared to rural councils. In Zia's case this appears to be an attempt to accommodate the interests of the urban middle classes that had formed the core of the anti-PPP movement. Thus in general, these changes appear to reflect the political judgment of the non-representative centre at particular historical junctures regarding the relevant political population that needed to be accommodated to deliver sustained political support at the local level. This judgment apparently based on the numerical importance of a population and by the ability of mobilized groups to impose heavy electoral, political and disruption costs on the state.

For example, the Punjab tradition of the British reflects the judgment that village proprietors had to be politically accommodated for they alone combined the required numerical strength with influence in rural society (van den Dungen 1972) and because Punjab’s rural areas had emerged as the major recruiting ground for the British army (Ali 1988). The increased rural payoffs under Ayub are also a reflection of his electoral and political support base, which came from the rural areas of West Pakistan (Rizvi 1976). Similarly, Zia's decision to sustain the rural-urban divide, in the context of rising urban council incomes, allowed the regime to accommodate Punjab's politically mobilized urban middle classes, whose rising income, political strength and agitational ability, a consequence of the socio-demographic changes that had taken place during the sixties and seventies, had amply manifested itself in the anti-Bhutto PNA movement. What is important is that the judgment of different regimes regarding the political importance of rural and urban areas appears to have differentially benefited these areas in terms of public spending at different levels of the state. We have shown in Section II that the current plan has reversed the trend set under the previous regimes as it has legislatively eliminated the rural-urban divide in local governments by integrating urban and rural local councils at the Tehsil level and by ensuring that a rural-urban distinction is not present within district governments. While the reasons behind the reversal of the rural-urban divide under the current reforms are not obvious, given that the previous rural-urban proclivities all reflected the changing importance of urban/rural constituents in harnessing local support and legitimacy, it is likely that the same reasons are at play. 
Thus it is plausible that the current decision to eliminate the rural-urban divide is partly explained by socio-demographic changes that have taken place in Pakistan since the eighties. Recent demographic work (Ali 2003) indicates that Pakistan's primary cities have emerged as major urban systems, with their rural suburbs or "peri-urban" settlements integrated into the city economies. This phenomenon is most apparent in Central Punjab's heartland where contiguous districts, comprising major cities, medium sized towns and peri-urban settlements have formed into a significant population agglomeration that has increased its political and economic importance (Ali 2003). More importantly, approximately half of this population resides in peri-urban settlements that had not been recognized as "urban" under the previous local government system, a legislative rule that denied them access to the administrative benefits associated with urban local councils such as Octroi revenue and better delivery of municipal services. ${ }^{46}$ The integration of urban and rural councils into Tehsil administrations will certainly benefit this population by creating tehsils where the peri-urban vote is in a majority. Similarly, benefits will accrue to peri-urban areas at the district level in Central Punjab as well, both because the peri-urban union councils of these districts control over half the union council votes in the electoral college of the District Nazim, and because the devolution of provincial functions to the districts ensures that the peri-urban population no longer has to compete with the rural majorities of other parts of the province as it would have had to in the provincial elections. Evidence of this accommodation of peri-urban areas comes from the National Reconstruction Bureau's (NRB) ${ }^{47}$ own documents which recognize that "there is urbanization in rural areas through peri-urban growth enveloping cities and ribbon urbanization along roads" (NRB-Local Government Plan 2002). Interestingly, according to the NRB, ultimately such urbanizing areas, whether they be peri-urban or tehsils towns, will form city districts and in "the Local Government Plan the city district ... is necessary to bridge the urban-rural divide and contribute to organized urbanisation rather than the chaotic situation that currently prevails” (ibid).

In general however, the effects of eliminating this urban-rural administrative distinction are not as simply classified: while we argued above that in Central Punjab this was likely to favor peri-urban areas, in the more agrarian regions, such as Sindh and Southern and Western Punjab (Gazdar 1999), this change is likely to benefit rural areas due to their majority rural vote as the relatively economically prosperous urban areas will now have to share the benefits of their incomes with their

\footnotetext{
${ }^{46}$ Andrabi and Cheema (2003) show that these settlements have done much worse than urban councils, even the smaller less prosperous ones (Town Committees), in terms of their access to key local services.

${ }^{47}$ Musharraf's think tank that spearheaded the design of the current Devolution Plan.
} 
rural and peri-urban hinterlands ${ }^{48}$. In this sense the Musharraf system is more flexible in that it allocates relative power to whatever demographic group is in majority in the local area.

\section{Concluding Thoughts}

This paper has argued that in order to understand the current decentralization in Pakistan it is imperative to view the reform in the historical context of previous such reforms. In particular a constant theme that emerges in this context is that these reforms have somewhat paradoxically been brought about by non-representative regimes such as the British during the pre-independence period and the military during the post-independence period. In fact each of the three military regimes in Pakistan has implemented local government reforms and each political government that has followed has undermined these reforms or at best simply ignored the local governments. These reforms have all involved decentralizing from the Province to local levels but often a recentralization at the Federal levels. Our interpretation is that these reforms have been used as a means for a non-representative centre to gain legitimacy by by-passing the political agents at the provincial and national levels.

Moreover, the conflict between the provincial representatives and local governments we have highlighted does not bode well for the future of the current decentralization program either. Already, with an elected provincial and national government in place, we have begun to see conflicts arising between the province and local governments. However, what is different about the current decentralization reforms is that they have gone much further in terms of their extent and scope. While the local governments still have little revenue raising abilities, and have effectively limited ability to decide their expenditures given that the majority expenditure is in the forms of fixed "establishment costs", the delivery of most public services has now come under their purview. While these local governments' future is still uncertain given their limited constitutional support and conflict with the provincial governments, what is clear is that if they remain, we are likely to see an impact on the delivery of these public services. Whether this will be for the better, as local governments may become more accountable to the general public, or for the worse, if local governments fall into patronage and "biraderi” politics, remains to be seen.

\footnotetext{
${ }^{48}$ Interestingly, despite the NRB-Local Government Plan's (2000) explicit recognition that there was a case for declaring the city areas in at least 11 districts of Pakistan as City Districts, the Musharraf regime chose to only declare the four Provincial Capitals as City Districts. This effectively gave the rural areas and rural politicians of the remaining 7 districts a claim over the resources of the larger and richer urban areas.
} 
Figure I.1: Structure of Local Governments under General Ayub - All Pakistan1965

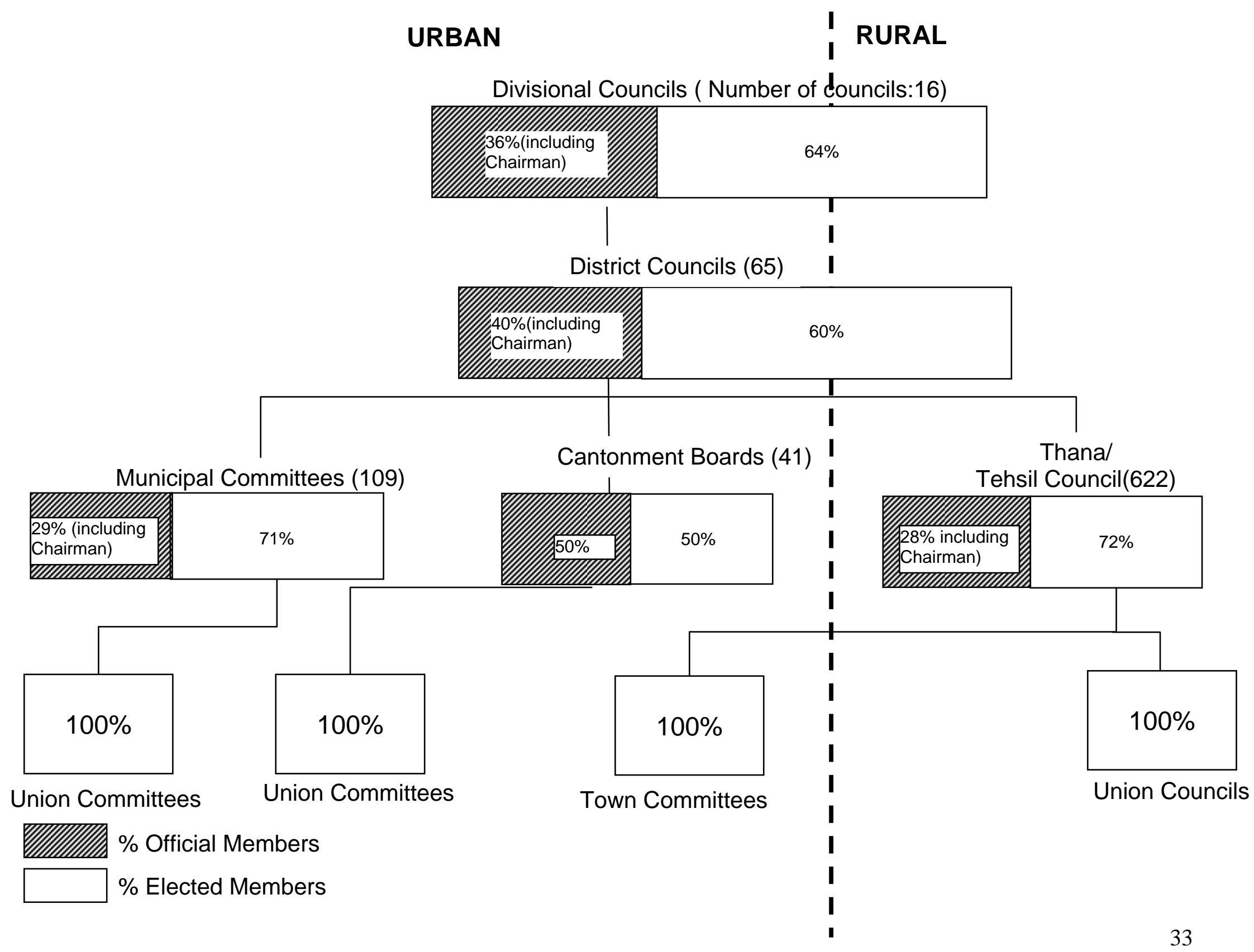




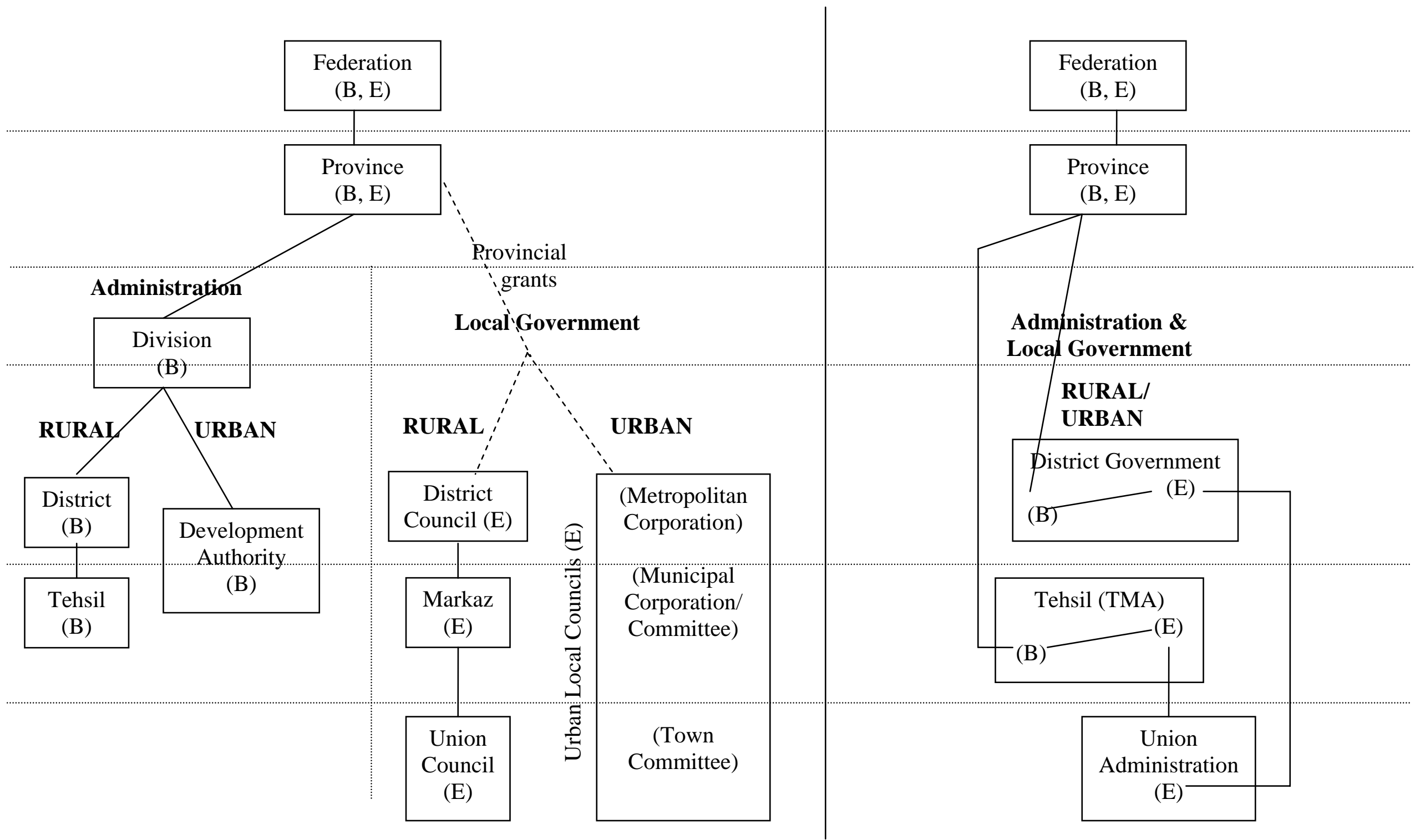

* Note: The police department is an exception to the above structure since it has not been devolved to the local level under the new structure. 
Figure II.3. Expenditure Shares in Aggregate Provincial and Local Government Spending

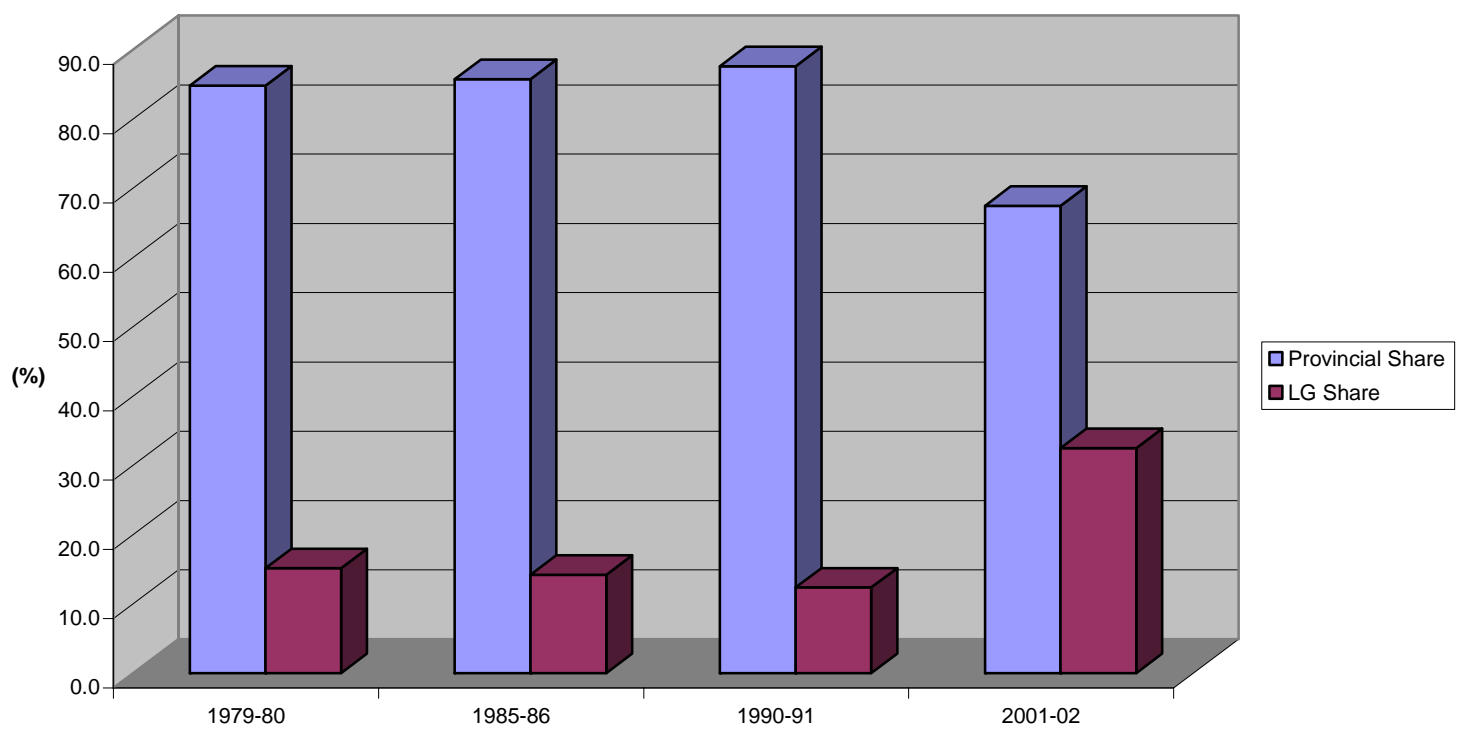

Source: AERC (1990) District Budgets 


\section{References}

Addleton, J. S (1992). Undermining the Centre: The Gulf Migration and Pakistan. New York: Oxford University Press.

Ahmed, M. (1964). The Civil Servant in Pakistan. Karachi: Oxford University Press.

Ahmed, V. and Amjad, R. (1984). The Management of Pakistan's Economy, 1947-82. Karachi: Oxford University Press.

Applied Economic Research Centre (AERC) (1990). Local Government Administration in Pakistan. Karachi: unpublished manuscript.

Alavi, H. (2001). "Parting of the Ways” in Z. Mustefa (eds.) The South Asian Century. Karachi: Oxford University Press.

Ali, I. A (1988). The Punjab under Imperialism, 1885-1947. Delhi: Oxford University Press.

Ali, R. (2003). “Understanding Urbanization,” in S. A. Zaidi (eds.) Continuity and Change: Socio Political and Institutional Dynamics in Pakistan. Karachi: City Press.

Andrabi, T. and A. Cheema (2003). "Reclassifying the Urban-Rural Divide in Punjab: public services and private responses in peri-urban areas,” Working Draft.

Arif, G. M. and S. Ibrahim (1998). "The Process of Urbanization in Pakistan, 1951-81,” Pakistan Development Review (Winter 1998).

Basham, A. L. (1954). The Wonder that was India. London.

Burki, S. J. (1971). "Social and Economic Determinants of Political Violence: A Case Study of the Punjab,” The Middle Eastern Journal 25 (Autumn).

Burki, S. J. (1972). “Ayub’s Fall: A Socio-Economic Explanation,” Asian Survey 12.

Burki, S. J. (1980). Pakistan Under Bhutto: 1971-77. London: Macmillan.

Burki S.J (1991). Pakistan: The Continuing Search for Nationhood. San Francisco: Westview Press.

Callard, K. (1957). Pakistan: A Political Study. London: George Allen and Unwin.

Cheema, A. and S. K. Mohmand (2003). "Local Government Reforms in Pakistan: Legitimising Centralization or a Driver for Pro-Poor Change?,” Paper written for the "Pakistan Drivers of ProPoor Change Study conducted by Institute of Development Studies UK, Collective for Social Science Research, Karachi. DFID, UK. 
Cheema, A. and A. U. Sayeed (2004). "Bureaucracy and Pro-Poor Change,” Paper written for the "Pakistan Drivers of Pro-Poor Change Study conducted by Institute of Development Studies UK, Collective for Social Science Research, Karachi. DFID, UK.

Drummond, J. G. (1937). Panchayats in India. London: Oxford University Press.

Feldman, H. (1967). Revolution in Pakistan: a Study of the Martial Law Administration. Karachi: Oxford University Press, 1967.

Feldman, H. (1972). From Crisis to Crisis: Pakistan 1962-69. London: Oxford University Press.

Friedman, H. J. (1960). “Pakistan’s Experiment in Basic Democracies,” Pacific Affairs XXXIII, June.

Gauhar, A. (1996). Ayub Khan: Pakistan’s First Military Ruler. Lahore: Sang-e-Meel.

Gazdar, H. (1999). “Poverty in Pakistan: A Review,” in S. R. Khan (eds.) Fifty Years of Pakistan's Economy. Karachi: Oxford University Press.

Hamid, N. (1980). Process of Agricultural Development - A Case Study of the Punjab. Doctoral Dissertation Stanford University.

Haq, M (1985). Interview with the Overseas Mashriq on June 27, 1985.

Hasan, A. (2002). The Unplanned Revolution. Karachi: The City Press.

Hyder, T. A. (1999). Municipal Management and Finance in Southern Punjab Islamabad: Water and Sanitation Program, World Bank.

Jalal, A. (1995). Democracy and Authoritarianism in Pakistan: A comparative and historical perspective. Lahore: Sang-e-Meel.

Khan, A.(1967). Friends Not Masters: A Political Autobiography. London: Oxford University Press.

Kumar, D. (1982). “The Fiscal System, “ in D. Kumar (eds.) The Cambridge Economic History of India. New Delhi: Orient Longman.

Local Government Ordinance (LGO) (1979). Lahore: Law Book Land.

Local Government Ordinance (LGO) (2001). The Punjab Gazette $8^{\text {th }}$ October 2001. Government of the Punjab: Law and Parliamentary Affairs department.

Local Government Plan (LGO) (2000). National Reconstruction Bureau.

Manning, N., D. Porter, J. Charlton, M. Cyan and Z. Hasnain (2003). Devolution in Pakistan Preparing for Service Delivery Improvements. Pakistan: World Bank. 
Majumdar, R.C. (1960). The History and Culture of Indian People, Vol. II. Bombay.

Metcalfe, T. R. (1962). "The British and the Moneylender in Nineteenth Century India," The Journal of Modern History, XXXIV December.

Nasim, A. (1999). Local Government Finance in the Punjab. Lahore: Punjab Municipal Development Fund Company.

Nath, A. (1929). Development of Local Self-Government in Punjab (1849-1900), Lahore.

Niazi, M. A. (1994) “Local Bodies: the history,” The Daily News on Friday, $30^{\text {th }}$ September.

Noman, O. (1988). Pakistan: Political and Economic History since 1947. London: Kegan Paul International.

Pasha, M. (1998) Colonial Political Economy: Recruitment and Underdevelopment in the Punjab.

Karachi: Oxford University Press.

Rizvi, S. A (1976) Changing Patterns of Local Government in Pakistan. Karachi: Pakistan Historical Society.

Rouse, S. (1983). “Systematic Injustices and Inequalities: 'Maalik’ and 'Raiya' in a Punjab Village,” in H. Gardezi and J. Rashid (eds.) Pakistan: The Unstable State. Lahore: Vanguard Books.

Sand, Klemens van de. (1976) Foundations and Problems of Local Government in Rural India. Bonn: v. Hase \& Koehler Verlag Mainz.

Sayeed, K. B. (1980). Politics in Pakistan: the Nature and Direction of Change. New York: Praeger.

Sayeed, A. U. (1995). Political Alignments, the State and Industrial Policy in Pakistan: a comparison of performance in the 1960s and the 1980s. Doctoral Dissertation, University of Cambridge.

Siddiqui, K. (1992). Local Government in South Asia. Dhaka: University Press Limited.

Talbot, I. (1996). “State Society and Identity: The British Punjab, 1875-1937,” in G. Singh and I. Talbot (eds.) Punjabi Identity: Continuity and Change. New Delhi: Manohar.

Talbot, I. (1998). Pakistan, A Modern History. New York: St. Martin’s Press.

Tinker, H. (1968). The Foundations of Local Self-Government in India, Pakistan and Burma. New York: Praeger.

Van den Dungen, P. H. (1972). The Punjab Tradition: Influence and Authority in Nineteenth Century India. London: George Allen and Unwin Ltd. 
Venkatarangaiya, M. and M. Pattabhiram (eds.) (1969) Local Government in India, select readings. Bombay: Allied Publishers.

Waseem, M. (1994). Politics and the State in Pakistan. Islamabad: National Institute of Historical and Cultural Research.

Waseem, M. (1997). “One Step Forward,” in C. Baxter and C. Kennedy (eds.) Pakistan 1997.

London: Westview Press.

Wilder, A. R. (1999). The Pakistani Voter: Electoral Politics and Voting Behavior in the Punjab. Karachi: Oxford University Press.

World Bank (1996). Supporting Fiscal Decentralization in Pakistan.

World Bank (1998). A Framework for Civil Service Reform in Pakistan.

World Bank (2000). Pakistan Reforming Provincial Finances in the Context of Devolution, An eight point agenda.

Zaidi, A. S. (1993). “The Hidden Revolution,” Herald, Election Special. Karachi.

Zaidi, A. S. (1999) Issues in Pakistan’s Economy. Karachi: Oxford University Press. 


\section{Appendix A: Chronology of Local Governments in Pre- and Post Independence Pakistan}

\begin{tabular}{|c|c|}
\hline Years & Event \\
\hline 1688 & Establishment of first Municipal Corporation in Madras \\
\hline 1842 & Enforcement of the Conservancy Act in Bombay Presidency \\
\hline 1850 & Promulgation of All India Municipal Act \\
\hline 1852 & Establishment of a municipality in Karachi \\
\hline 1862 & $\begin{array}{l}\text { Resolution passed by Lt. Governor of Punjab setting up Municipal Committees in District } \\
\text { Headquarters }\end{array}$ \\
\hline 1867 & $\begin{array}{l}\text { Promulgation of the Punjab Municipal Act. This Act created committees of officials and non- } \\
\text { officials for police and sanitation, with the Deputy Commissioner as President }\end{array}$ \\
\hline 1870 & $\begin{array}{l}\text { Mayo’s Resolution empowering Provincial Governments to introduce an elective element into } \\
\text { Municipal Committees }\end{array}$ \\
\hline 1870 & $\begin{array}{l}\text { Village Chaukadari Act passed empowering district magistrates to create nominated } \\
\text { Chaukadari Panchayats in villages for the maintenance of village peace }\end{array}$ \\
\hline 1873 & Amended Municipal Act passed in Punjab and Bombay (including Sindh) \\
\hline 1882 & $\begin{array}{l}\text { Lord Rippon's Resolution on Local Self-Government. This resolution called for the } \\
\text { establishment of elected Municipal Committees, District and Taluka Boards }\end{array}$ \\
\hline 1884 & $\begin{array}{l}\text { Passage of the Amended Municipal Act in Punjab, Bombay and Bengal. This amended Act } \\
\text { created a provision for the election of the Chairmen of the Municipal Committees }\end{array}$ \\
\hline 1901 & $\begin{array}{l}\text { Amended Municipal Act passed in Bombay. Created more elaborate municipal organizations in } \\
\text { larger cities and gave special powers to the chief executives }\end{array}$ \\
\hline 1907 & $\begin{array}{l}\text { Formation of the Decentralization Commission. Recommended the creation of non-official } \\
\text { chairmen of municipal committees. }\end{array}$ \\
\hline 1911 & Enactment of a new Punjab Municipal Act. This enactment maintained the status-quo. \\
\hline 1912 & Panchayat Act established panchayati institutions in rural villages. \\
\hline 1919 & Government of India Act. Local Government became a transferred subject to the provinces. \\
\hline 1922 & $\begin{array}{l}\text { Enactment of Improvement Trust Act in the Punjab. Established Improvement Trusts in larger } \\
\text { cities for regulating town planning. }\end{array}$ \\
\hline 1931 & $\begin{array}{l}\text { Executive Officers Act passed. Created a provision for the appointment of executive officers in } \\
\text { local councils. }\end{array}$ \\
\hline 1933 & Passage of City of Karachi Act. Granted Karachi the status of a Municipal Corporation. \\
\hline 1935 & $\begin{array}{l}\text { New Government of India Act passed. Granted provincial autonomy with power to frame } \\
\text { legislation on local government systems. }\end{array}$ \\
\hline 1941 & Enactment of Lahore Corporation Act. Declared Lahore to be a Corporation. \\
\hline 1947 & $\begin{array}{l}\text { Local Authority Service Act passed in Sindh. Provincialized the key posts in local } \\
\text { governments. }\end{array}$ \\
\hline 1947-59 & Continued operation of 1911 Punjab Municipal Act. Period of inactivity. \\
\hline 1959 & Basic Democracies Ordinance enacted by General Ayub Khan. Abolished in 1972. \\
\hline 1960 & Municipal Administration Ordinance 1960. Abolished in 1972. \\
\hline 1972 & $\begin{array}{l}\text { Enactment of People’s Local Government Ordinance } 1972 \text { by the PPP government. } \\
\text { Promulgated but not implemented. }\end{array}$ \\
\hline 1975 & $\begin{array}{l}\text { Enactment of People’s Local Government Act } 1975 \text { by the PPP government. Promulgated but } \\
\text { not implemented. }\end{array}$ \\
\hline 1979 & Local Government Ordinance enacted by General Zia-ul-Haq \\
\hline 2001 & Local Government Ordinance enacted by General Pervaiz Musharraf. \\
\hline
\end{tabular}




\section{Appendix B: The Electoral Mechanics of the Local Government}

The elected local government structure under the latest devolution of power plan (Gen. Musharraf) is as follows (refer to Manning et. al. 2003 for details):

- Union Council: The lowest level of elected government is at the union council level, which, with an average population of 25,000, corresponds roughly to several small villages or subvillages and sub-towns in the larger settlements. Each union council consists of 21 members elected on a non-party basis and headed by the union council nazim and naib-nazim who are both elected on a joint ticket.

- Tehsil Council: The Tehsil council consists of the directly elected union naib-nazims and around one-third indirectly elected members (minorities, women, peasant/workers) including the head of the Tehsil council, the Tehsil nazim and Tehsil naib-nazim.

- District Council: The District council consists of the directly elected union council nazims and around one-third indirectly elected members (minorities, women, peasant/workers) including the head of the district council, the district nazim and district naib-nazim.

Thus while the electorate for the union council is all registered voters who are Pakistani citizens and 18 years or older, the electorate for the other two levels of local government, are all the unioncouncil members who have been directly elected in the union council elections i.e. around 420 union councilors for the Tehsil and 1260 for the district (assuming 20 union councils in a Tehsil and 60 in a district). 